\title{
Population dynamics and secondary production of the cockle Cerastoderma edule (L.) in a backbarrier tidal flat of the Wadden Sea*
}

\author{
MONTSERRAT RAMÓN \\ Institut de Ciències del Mar (CSIC), Passeig Marítim de la Barceloneta, 37-49, 08003 Barcelona, Spain. \\ E-mail:mramon@icm.csic.es
}

\begin{abstract}
SUMMARY: The population biology of the bivalve Cerastoderma edule was studied by monthly sampling from April 1994 to September 1995 at Neuharlingersieler Nacken, a backbarrier tidal flat near Spiekeroog island (East Frisian Wadden Sea, North Sea). Four stations located along a tidal gradient from 56 to $80 \%$ immersion time were established in order to analyse cockle growth, mortality and production. The highest densities were recorded at the beginning of the study (1000-1250 ind. $\mathrm{m}^{-2}$ ) with an intense and progressive decrease through 1995. A spatial distribution pattern was observed during summer 1994, with juveniles (3-12 mm long) being found in the high intertidal whereas adults occurred along the middle and lower intertidal. Based on growth increment data from tagging-recapture experiments, the parameters of the von Bertalanffy growth curve were estimated to be: asymptotic length $\mathrm{L}_{\infty}=40 \mathrm{~mm}$, and growth constant $\mathrm{K}=0.404 \mathrm{y}^{-1}$. A growth ring was formed in summer (July-August 1994). Annual somatic production ranged between 38.16 and $59.33 \mathrm{~g} \mathrm{AFDW} \cdot \mathrm{m}^{-2} \cdot \mathrm{y}^{-1}$. Total mortality ranged between $\mathrm{Z}=0.52$ year $^{-1}$ and $\mathrm{Z}=3.03$ year $^{-1}$. The distribution of the population was affected by passive displacements of juvenile cockles from the upper part of the intertidal toward lower zones in combination with high mortality at the station farthest from the coast, probably resulting from mussels overlying.
\end{abstract}

Key words: Cerastoderma edule, cockle, growth, mortality, biomass, production, Wadden Sea.

RESUMEN: DINÁMICA DE POBLACIÓN Y PRODUCCIÓN SECUNDARIA DEL BERBERECHO CERASTODERMA EDULE (L.) EN UNA ZONA INTERMAREAL DEL MAR DE WADDEN. - Se ha estudiado la dinámica de la población del bivalvo Cerastoderma edule en Neuharlingersieler Nacken, una zona intermareal de la isla de Spiekeroog (mar del Norte), realizando muestreos mensuales entre abril de 1994 y septiembre de 1995. Al objeto de analizar su crecimiento, mortalidad y producción se establecieron cuatro estaciones a lo largo de un gradiente mareal, dispuestas en fondos sumergidos entre el 56 y el $80 \%$ del tiempo. Al inicio del estudio se registraron las densidades más elevadas (1000-1250 ind. $\mathrm{m}^{-2}$, produciéndose una disminución intensa y progresiva a lo largo de 1995. En el verano de 1994 se observó que los juveniles (3-12 milímetros de longitud) estaban localizados en la zona superior del intermareal mientras que los adultos ocupaban las zonas más bajas. En base a los datos de incrementos del crecimiento obtenidos en experiencias de marcado y recaptura, se estimaron los siguientes parámetros de la función de crecimiento de von Bertalanffy: longitud asintótica $\mathrm{L}_{\infty}=40 \mathrm{~mm}$ y la constante de crecimiento $\mathrm{K}=0,404$ $\mathrm{año}^{-1}$. Se observó la formación de un anillo de crecimiento entre julio y agosto de 1994. La producción somática anual osciló entre 38,16 y 59,33 g PSLC m${ }^{-2}$. año ${ }^{-1}$. La mortalidad total osciló entre $Z=0,52$ año $^{-1}$ y Z $=3,03$ año $^{-1}$. La distribución de la población se vió afectada por movimientos pasivos de los juveniles desde la zona superior del intermareal hacia las zonas más bajas y por una elevada mortalidad en la estación más alejada de la costa, posiblemente ocasionada por el establecimiento de un banco de mejillones.

Palabras clave: Cerastoderma edule, berberecho, crecimiento, mortalidad, biomasa, producción, mar de Wadden.

*Received April 24, 2003. Accepted July 15, 2003. 


\section{INTRODUCTION}

The Wadden Sea is a shallow coastal area with extensive tidal flats. The western part and most of the Niedersachsen and Danish Wadden Sea are sheltered by barrier islands and almost $80 \%$ of the surface is exposed at low tide. Cerastoderma edule (L.) is a common inhabitant of intertidal areas along the north-west European coast. It is one of the most abundant species of the macrozoobenthos living on the tidal flats of the Dutch (Beukema, 1979), German (Dörjes et al., 1986; Reise et al., 1994) and Danish Wadden Sea (Jensen, 1992a), where it represents 8$60 \%$ of the total macrobenthic biomass. Locally, it can occur in dense assemblages of several thousand individuals per $\mathrm{m}^{2}$ (Jensen, 1992b), although in the Dutch Wadden Sea densities of adult cockles do not usually exceed 100-500 per $\mathrm{m}^{2}$ (Beukema, 1982a). Cockles are one of the main food sources for shrimps (Crangon crangon), flatfish (Pleuronectes), shore crabs (Carcinus maenas), oystercatchers (Haematopus ostralegus), herring gulls (Larus argentatus) and eiders (Somateria mollissima) (Reise, 1985; Jensen and Jensen, 1985), and are the target species of a local fishery in several countries (Britain, France, Netherlands, Spain). Heavy fluctuations of the populations as a result of high variability in both success of spatfall and subsequent survival have been related to environmental factors. Physical conditions like sediment quality (Ducrotoy and Desprez, 1986) and dynamics (Bouma et al., 2001), severe winters (Beukema, 1979, Strasser, 2000), storm-generated waves (Nehls and Thiel, 1993) and high levels of silt and biodeposits (Flemming and Delafontaine, 1994) are important factors controlling the development of the bivalve populations on these tidal flat areas, although biological factors like predation (Guillou and Tartu, 1994, Strasser and Günter, 2001) and competition (André and Rosenberg, 1991; Kamermans, 1993) also play their part.

Previous studies on the Wadden Sea cockle populations analysed changes in the benthic macrofauna (Beukema, 1979, 1992; Jepsen, 1965; Müller, 1966; Dörjes et al., 1986; Reise, 1987 and Reise et al., 1994), seasonal variation in body weight (Zwarts, 1991), growth and dynamics (Jensen 1992a,b and Dörjes, 1992) and recruitment (Strasser, 2000 and Bouma et al., 2001). None of these studies provides detailed quantitative data on the population dynamics by analysing simultaneously juvenile and adult distribution, growth, biomass, production and mortality.
The aim of this study was: (1) to estimate the population characteristics (structure, growth, secondary production and mortality) of a C. edule population combining standard methodologies in marine ecology and fishery biology such as taggingrecapture experiments, and (2) to compare the growth parameters with previous reported data.

\section{MATERIAL AND METHODS}

\section{Study area}

The study was conducted on the Neuharlingersieler Nacken, a tidal flat in the backbarrier area of Spiekeroog island (East Frisian Wadden Sea, North Sea) (Fig. 1A). Tides are semidiurnal and the mean tidal range is $2.7 \mathrm{~m}$. The shoreward margin of this tidal flat is dominated by very fine sand (3.0-5.5 phi), which reaches concentration levels of $>70 \%$ by weight (Flemming and Nyandwi, 1994). Values of water surface temperature, salinity and functional chlorophyll- $a$ determined in the Harle tidal inlet (between Spiekeroog and Wangerooge) are shown in Figure 2 (data are from the Forschungsstelle Küste, 1995, 1996). The maximum recorded temperature was $21{ }^{\circ} \mathrm{C}$ in summer, whereas in winter the water surface was frozen for short periods when it was impossible to take samples. Salinity normally ranged from 28 to $34 \%$. Chlorophyll- $a$ values ranged from 3 to $22 \mathrm{mg} \cdot \mathrm{m}^{-3}$, with the highest concentrations in early May due to blooms of the flagellate Phaeocystis globosa.

\section{Sampling}

Live specimens of Cerastoderma edule were collected monthly from April 1994 to September 1995 at four sampling stations (coded 1 to 4 ) situated in a transect along a tidal gradient (Fig. 1B). Observations made in August 1994 showed the presence of juveniles of $C$. edule from 3 to $12 \mathrm{~mm}$ long between the shoreline and Station 1. In order to follow the development of this new cohort (the 1994 cohort), a new transect with 7 stations (coded A to G, Fig. 1B) was added between the shoreline and Station 1. The topographic elevation relative to chart datum (CD), the distance of each station from mean high water level (MHWL), submersion time and sediment characteristics can be seen in Table 1 .

Five samples covering an area of $0.0625 \mathrm{~m}^{2}$ each were taken at random from each station, defined as an area of about $64 \mathrm{~m}^{2}$ around a station 


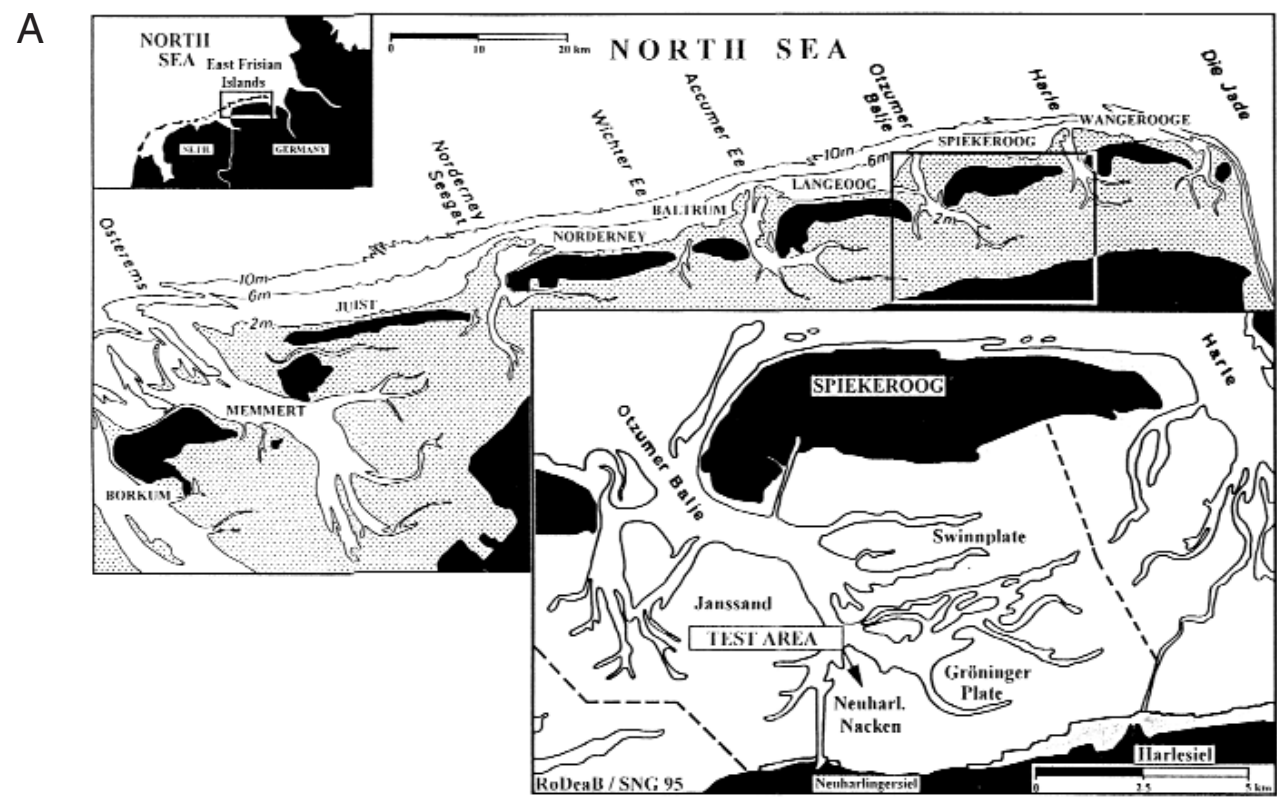

B

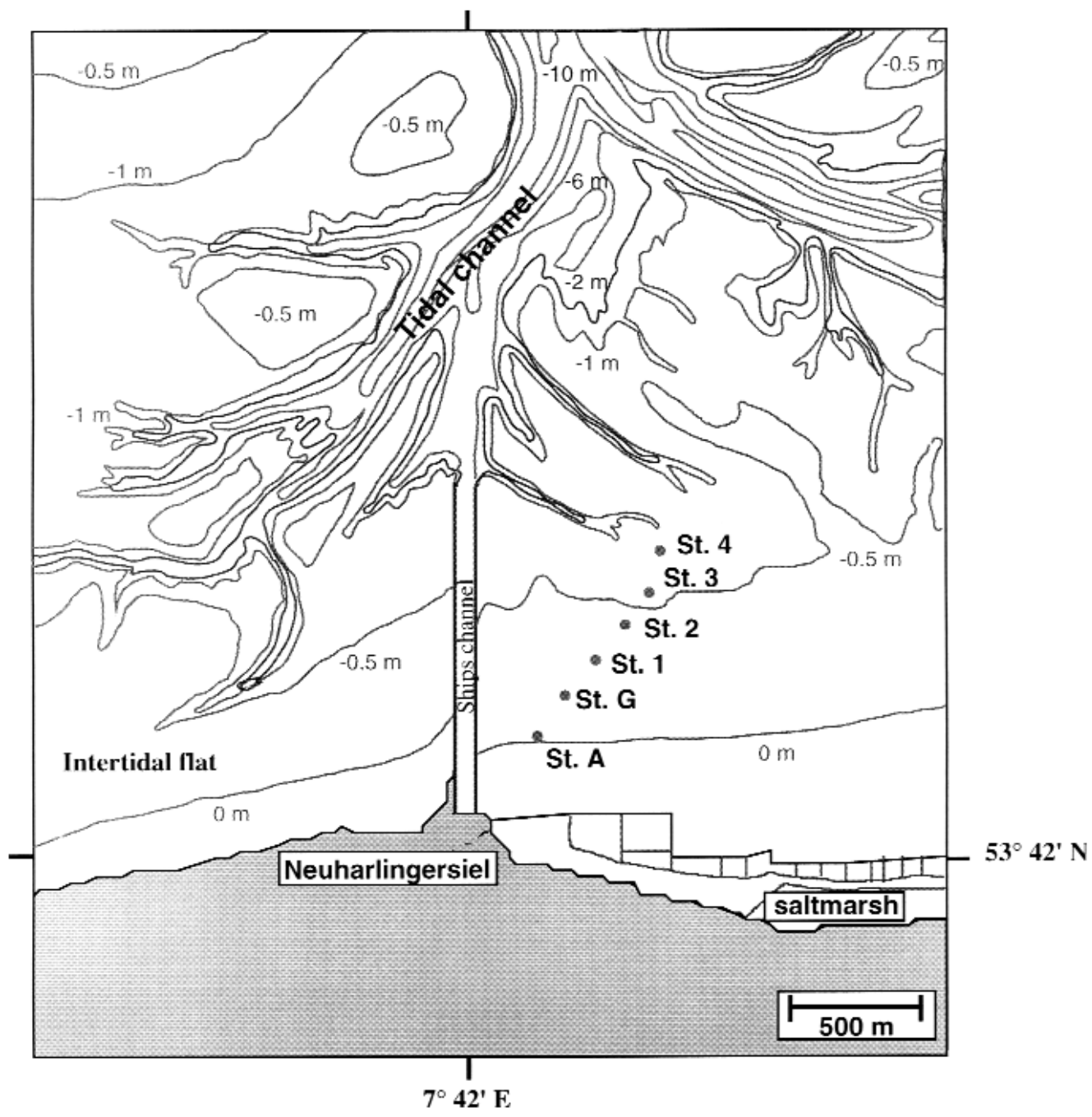

FIG. 1. - A: map of the study area. B: location of sampling stations on the Neuharlingersieler Nacken tidal flat. Stations B to F were situated between Stations A and G in a straight line. 
Temperature

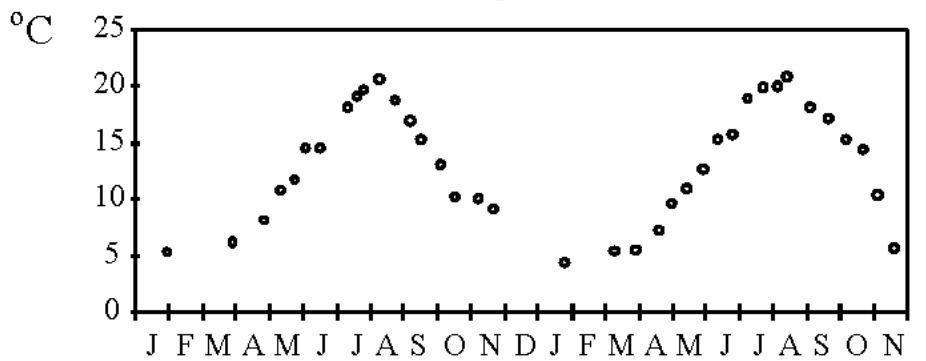

Salinity

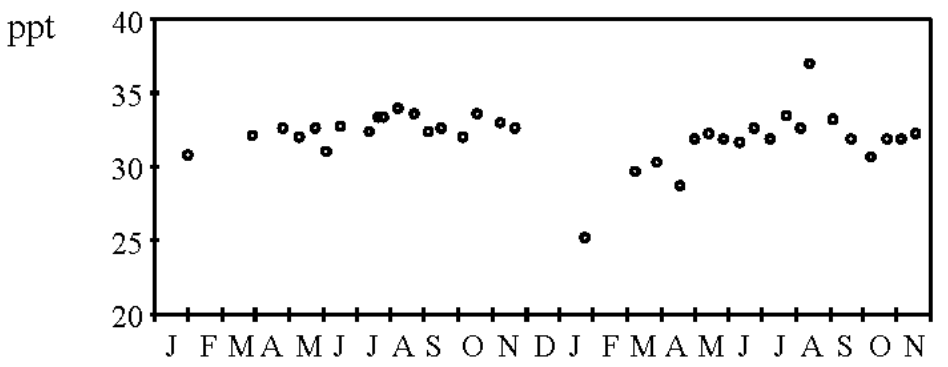

Chlorophyll-a

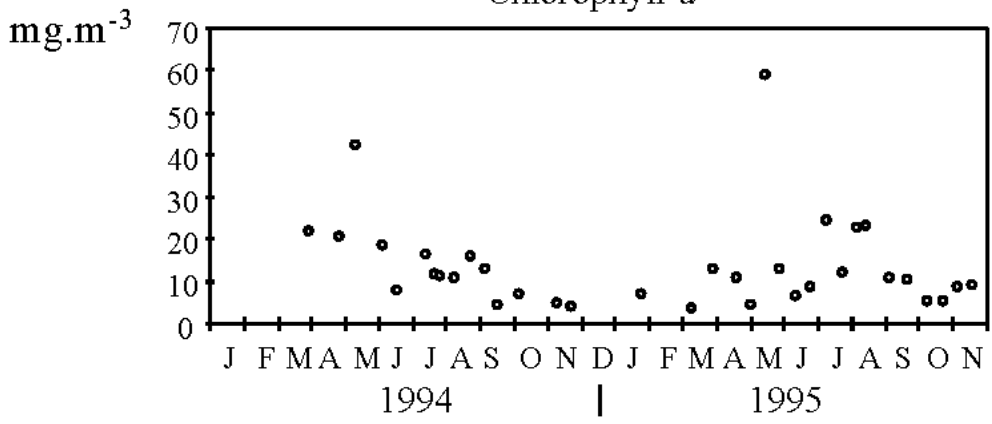

FIG. 2. - Monthly sea surface temperature, salinity and chlorophyll- $a$ in Harle (eastern part of Spiekeroog) in 1994 and 1995.

TABLE 1. - Elevation relative to chart datum (CD), distance from mean high water level (MHWL), submersion time and sediment components (in percentages) of the stations in Neuharlingersieler Nacken studied. The sediment sampling was carried out twice, in March and September 1995 (B. W. Flemming, unpublished data).

\begin{tabular}{|c|c|c|c|c|c|c|}
\hline $\begin{array}{l}\text { Sampling } \\
\text { stations }\end{array}$ & $\begin{array}{l}\text { Elevation relative } \\
\text { to } C D(\mathrm{~cm})\end{array}$ & $\begin{array}{l}\text { Distance from } \\
\text { MHWL (m) }\end{array}$ & $\begin{array}{l}\text { Submersion } \\
\text { time }(\%)\end{array}$ & $\begin{array}{l}\text { Sediment sampling } \\
\text { date }\end{array}$ & Sand $(\%)$ & Mud (\%) \\
\hline A & 37 & 325 & 48 & $\begin{array}{l}03 / 95 \\
09 / 95\end{array}$ & $\begin{array}{l}91.69 \\
86.86\end{array}$ & $\begin{array}{c}8.31 \\
13.14\end{array}$ \\
\hline G & 5 & 505 & 54 & $\begin{array}{l}03 / 95 \\
09 / 95\end{array}$ & & \\
\hline 1 & -15 & 675 & 56 & $\begin{array}{l}03 / 95 \\
09 / 95\end{array}$ & $\begin{array}{l}72.78 \\
74.78\end{array}$ & $\begin{array}{l}27.22 \\
25.22\end{array}$ \\
\hline 2 & -29 & 875 & 60 & $\begin{array}{l}03 / 95 \\
09 / 95\end{array}$ & $\begin{array}{l}80.45 \\
79.87\end{array}$ & $\begin{array}{l}19.55 \\
20.13\end{array}$ \\
\hline 3 & -39 & 1040 & 63 & $\begin{array}{l}03 / 95 \\
09 / 95\end{array}$ & $\begin{array}{l}80.23 \\
84.53\end{array}$ & $\begin{array}{l}19.77 \\
15.47\end{array}$ \\
\hline 4 & -71 & 1200 & 80 & $\begin{array}{l}03 / 95 \\
09 / 95\end{array}$ & $\begin{array}{l}60.48 \\
50.46\end{array}$ & $\begin{array}{l}39.52 \\
49.54\end{array}$ \\
\hline
\end{tabular}


TABLE 2. - Tagging-recapture experiment: number of Cerastoderma edule (tagged and untagged) and sampling period of the different experiments.

\begin{tabular}{lccccc}
\hline Cage number & Tagged individuals & Untagged individuals & Initial date & Recovery date & Experiment duration (days) \\
\hline 1 & 32 & 280 & $5 / 05 / 94$ & $6 / 06 / 94$ & 32 \\
1 & 49 & 193 & $9 / 06 / 94$ & $12 / 07 / 94$ & 33 \\
1 & 49 & 279 & $15 / 07 / 94$ & $16 / 08 / 94$ & 32 \\
1 & 60 & 173 & $19 / 08 / 94$ & $27 / 09 / 94$ & 39 \\
1 & 83 & 126 & $30 / 09 / 94$ & $8 / 1 / 94$ & 39 \\
1 & 79 & 277 & $10 / 11 / 94$ & $23 / 03 / 95$ & 68 \\
2 & 35 & 278 & $5 / 05 / 94$ & $12 / 07 / 94$ & 74 \\
2 & 50 & 80 & $15 / 07 / 94$ & $27 / 09 / 94$ & 174 \\
3 & 91 & 182 & $50 / 09 / 94$ & $23 / 03 / 95$ & 103 \\
3 & 34 & 279 & $19 / 05 / 94$ & $16 / 08 / 94$ & 216 \\
4 & 51 & $15 / 07 / 94$ & $23 / 03 / 95$ & 116 \\
\hline
\end{tabular}

mark. A $0.25 \times 0.25 \mathrm{~m}$ frame was placed on the bottom, and the substrate inside the frame was dug up to a depth of ca. $4 \mathrm{~cm}$. Live cockles were collected by hand and the sediment was sieved through $3 \mathrm{~mm}$ mesh to check for the presence of small individuals. Specimens were measured in the laboratory with a Vernier calliper to the nearest 0.1 $\mathrm{mm}$ (antero-posterior axis).

Dry weight (DW) was determined by drying somatic tissue at $60^{\circ} \mathrm{C}$ for $48 \mathrm{~h}$. Subsequently the tissue was burned in a furnace for $2 \mathrm{~h}$ at $500^{\circ} \mathrm{C}$ to determine the somatic ash-free dry weight (AFDW).

\section{Growth, production and mortality analysis}

\section{Growth}

Methods for studying growth in bivalves include the analysis of size-frequency distributions, counting of well-defined annual rings and/or measurement of marked animals kept in experimental cages. Previous studies on $C$. edule growth are based on one or several of these methodologies (De Montaudouin, 1996; Kristensen, 1957; Iglesias and Navarro, 1990; Jensen, 1992b, 1993). In the present study it was decided to perform tagging-recapture experiments because the application of cohort analysis (method of Bhattacharya, 1967) to the size-frequency distributions of previously collected samples did not give clear results. Additionally, the presence of a recently formed ring at the edge of the shells of some individuals collected in August 1994 indicated that counting growth rings to age the individuals was not a reliable method in the study area because it is possible to find more than one ring per year.

C. edule specimens from 7 to $39 \mathrm{~mm}$ length were collected and transferred to the laboratory. They were tagged with plastic labels glued to the right valve with adhesive cyanoacrilate and were transferred to 4 experimental cages located at Station 4. Each cage $(50 \mathrm{~cm} \times 50 \mathrm{~cm} \times 10 \mathrm{~cm})$ consisted of a stainless steel frame open at the top and bottom with sides of $1 \mathrm{~cm}$ stainless steel mesh (Ramón, 1996). They were dug in flush with the sediment surface in areas initially cleared of cockles. Fish netting $(1 \mathrm{~cm}$ mesh size) was secured to the tops of the cages in order to prevent emigration and immigration. Each cage contained the number of cockles necessary to maintain natural densities, although most of the cockles were not tagged. After different time intervals the individuals were recovered and the tagged ones were measured. Later new individuals (tagged and untagged) were placed in the cages to continue the experiment. Experiments were carried out from May 1994 to March 1995, resulting in 12 sets of tagging-recapture data (Table 2). Individual growth was measured as the increase in shell length between the beginning and the end of the experiment.

To compare growth rates of cockles in the different experimental periods used in the tagging-recapture experiment, the influence of different initial lengths on growth must be removed. One way of doing this is by fitting a growth equation to the pooled data set of initial and final lengths. The differences between the observed final lengths and final lengths predicted by this curve (residuals) were compared by ANOVA. The von Bertalanffy growth model (von Bertalanffy, 1938), generally used in intraspecific comparisons of growth rates of bivalve molluscs, was used to describe growth of C. edule. The parameters of the function were estimated by an iterative non-linear least-square method (SIMPLEX algorithm, Press et al., 1986) which was applied to the re-arranged growth function:

$$
\mathrm{L}_{2}=\mathrm{L}_{1}+\left(\mathrm{L}_{\infty}-\mathrm{L}_{1}\right) \cdot\left[1-\mathrm{e}^{-\mathrm{k} \cdot(\mathrm{t} 2-\mathrm{t} 1)}\right]
$$


where $\mathrm{L}_{1}$ is the length at the beginning and $\mathrm{L}_{2}$ the length at the end of the time interval $t_{2}-t_{1}$ For $t_{0}$ no estimate can be obtained from growth increment data.

The growth index phi prime ( $\left.\phi^{\prime}\right)$ defined as: $\phi^{\prime}=$ $2 \log _{10}\left(\mathrm{~L}_{\infty}\right)+\log 10 \mathrm{~K}$ (Pauly and Munro, 1984) was used to measure growth performance. This criterion was chosen because the negative correlation between $\mathrm{K}$ and $\mathrm{L}_{\infty}$ invalidates comparisons based on individual parameters.

\section{Secondary production}

The weight-specific growth rate method (Crisp, 1984) was used to calculate annual somatic production P, using growth rates as a function of size and adding throughout the year for each size class present:

$$
\mathrm{P}=\Sigma \Sigma \mathrm{N}_{\mathrm{i}} \cdot \mathrm{W}_{\mathrm{i}} \cdot \mathrm{G}_{\mathrm{i}} \cdot \Delta \mathrm{t} \quad\left(\mathrm{g} \text { AFDW } \cdot \mathrm{m}^{-2} \cdot \mathrm{y}^{-1}\right)
$$

where $\mathrm{N}_{\mathrm{i}}$ is the mean number of individuals $\left(\mathrm{N} \cdot \mathrm{m}^{-2}\right)$ existing in the population during the period $\Delta \mathrm{t}, \mathrm{W}_{\mathrm{i}}$ the mean body weight (g AFDW) of the length class $\mathrm{i}$, and $\mathrm{G}_{\mathrm{i}}$ the weight-specific growth rate:

$$
\mathrm{G}_{\mathrm{i}}=\mathrm{b} \cdot \mathrm{K}\left[\left(\mathrm{L}_{\infty} / \mathrm{L}_{\mathrm{i}}\right)^{-1}\right]\left(\mathrm{y}^{-1}\right)
$$

where $b$ is the exponent of the length-weight relationship (calculated to be AFDW $(\mathrm{mg})=0.00462 *$ length $3.127(\mathrm{~mm})$ ), $\mathrm{L}_{\infty}$ and $\mathrm{K}$ are VBGF parameters and $\mathrm{L}_{\mathrm{i}}$ is the mean length in length class $\mathrm{i}$. Annual mean biomass B (in $\mathrm{g}$ AFDW $\mathrm{m}^{-2}$ ) was calculated as follows:

$$
\mathrm{B}=\Sigma \mathrm{N}_{\mathrm{i}} \cdot \mathrm{W}_{\mathrm{i}}
$$

The annual $\mathrm{P} / \mathrm{B}$ ratio was calculated from annual somatic production $\mathrm{P}$ and annual mean biomass $\mathrm{B}$.

\section{Mortality}

The population mortality of Cerastoderma edule in Neuharlingersieler Nacken is expressed as follows:

- mortality rate $(\mathrm{Q})$, calculating the proportion of individuals missing between two sampling periods: $\mathrm{Q}=\left(\mathrm{N}_{0}-\mathrm{N}_{\mathrm{t}}\right) / \mathrm{N}_{0}$, with survival $\mathrm{S}=1-\mathrm{Q}$.

- instantaneous rate of total mortality (Z), considering that the number of dead individuals is proportional to the number of $\mathrm{N}$ individuals present at a time $\mathrm{t}: \mathrm{dN} / \mathrm{dt}=-\mathrm{Z} \mathrm{N}$. Then $\mathrm{Z}$ will be estimated by simple linear regression using the seasonal varia- tions of the number of individuals at each sampling station:

$$
\mathrm{Z}=-\left(\ln \mathrm{N}_{\mathrm{t}+1}-\ln \mathrm{N}_{\mathrm{t}}\right) /(\mathrm{t}+1-\mathrm{t})
$$

Mortality rate and growth curves of the 1994 cohort (recruits) were obtained by means of the analysis of the size-frequency distribution, since the new cohort was easy to separate from the older year classes.

\section{RESULTS}

\section{Population structure and distribution}

Adults of the Cerastoderma edule population were distributed between Station 1 as the upper limit of occurrence and Station 4 as the lower limit of occurrence at the time of the study. In late July 1994, clumps composed of newly settled Mytilus edulis attached to live and dead $C$. edule were observed. Clumps were rare at Stations 1 and 3 and abundant at Stations 2 and 4 (Ramón, 1996). Cockles attached to clumps represented $4-10 \%$ and $15-22 \%$ of total cockles at Stations 2 and 4 respectively. Three months later, the amount of clumps (between 45 and 85 clumps $\cdot \mathrm{m}^{-2}$ ) and the total number of mussels attached in clumps (600 mussels. $\mathrm{m}^{-2}$ ) were high only at Station 4. A young mussel bank was established to the north of this station in areas devoid of cockles.

C. edule densities at the beginning of the study (May 1994) were similar at Stations 1, 2, 3 and 4, about 1,000 and 1,250 ind. $\mathrm{m}^{-2}$ on average (Fig. 3). Density changes showed a similar trend at Stations 1, 2 and 3, with a sharp decrease between November and December 1994 and during 1995. Station 4 showed a progressive reduction in density throughout the study period. By the end of the study (September 1995) densities at Stations 1, 2 and 3 had decreased to 400-500 ind. $\mathrm{m}^{-2}$, whilst at Station 4 the density was only 29 ind. $\mathrm{m}^{-2}$.

\section{Recruitment}

The recruitment of $C$. edule (the 1994 cohort) took place during summer 1994, indicated in August by the presence of juveniles (3-12 $\mathrm{mm}$ long) between the shoreline and Station 1. The density of juveniles varied between 80 and 275 ind. $\mathrm{m}^{-2}$ from stations A to G. Juveniles were absent from Stations $1,2,3$ and 4 at that time. The spatial distribution pat- 

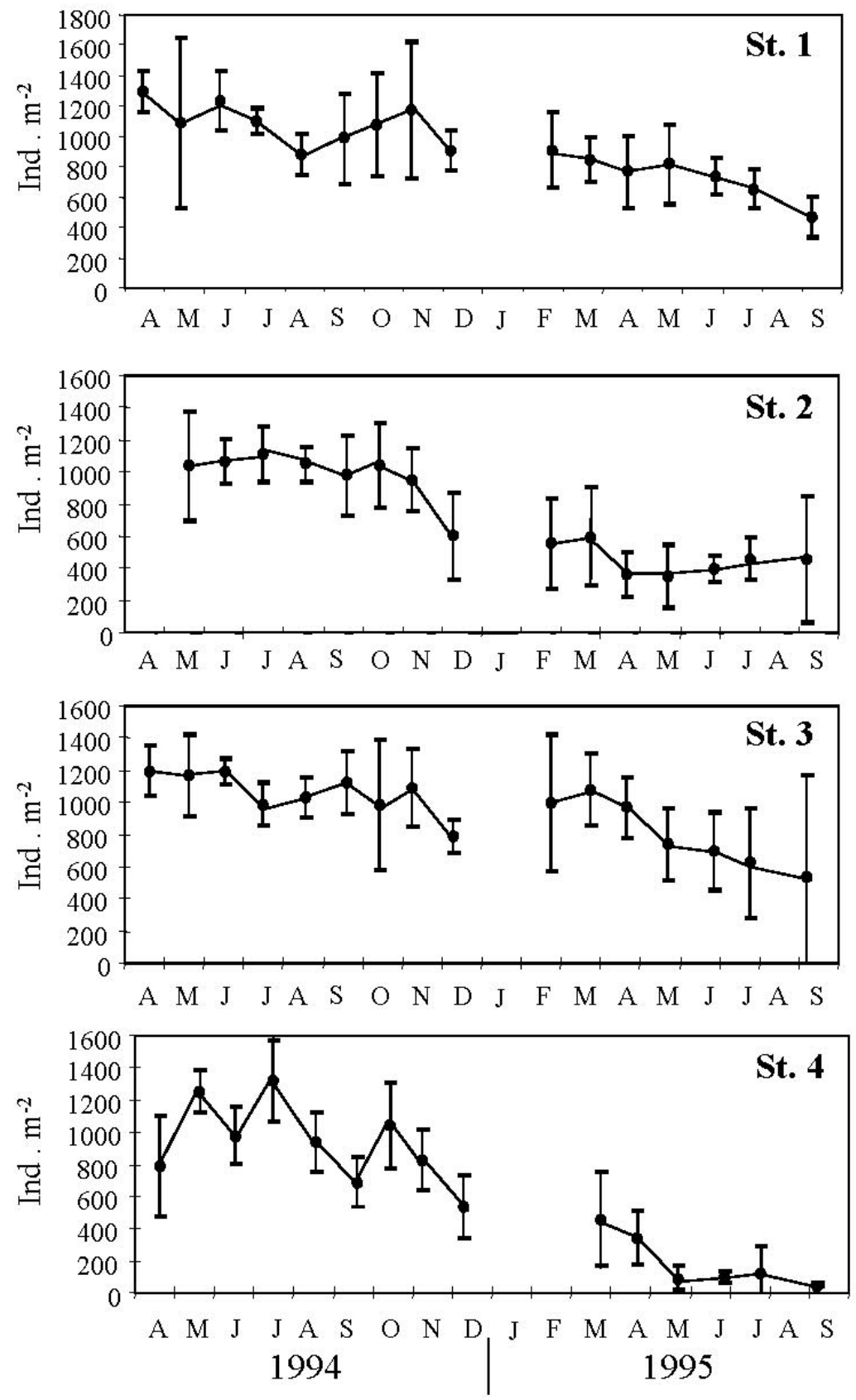

FIG. 3. - Mean densities ( \pm S.D.) of the adult population of Cerastoderma edule at the four stations studied from early 1994 to late 1995 .

tern of juveniles from $A$ to $G$ was maintained throughout the study period (as an example, Fig. 4 shows the length frequency distribution of the recruits from Stations A to G in September 1994). The population was mainly composed of juveniles at Stations A, B, C and D; at Station E the number of adults increased and the proportion of juveniles and adults reached similar values, while at Stations F and $G$ the population was composed mainly of adults, and was similar to the population composition at Station 1.
In February 1995 a large number of juveniles (the 1994 cohort) was observed at Station 1 (Fig. 5), whilst their presence at Stations 2, 3 and 4 was insignificant. No recruitment was observed in 1995 in the study area.

\section{Growth}

The length frequency distributions of the $C$. edule adult population did not show clear peaks for different cohorts which enabled their growth to be 


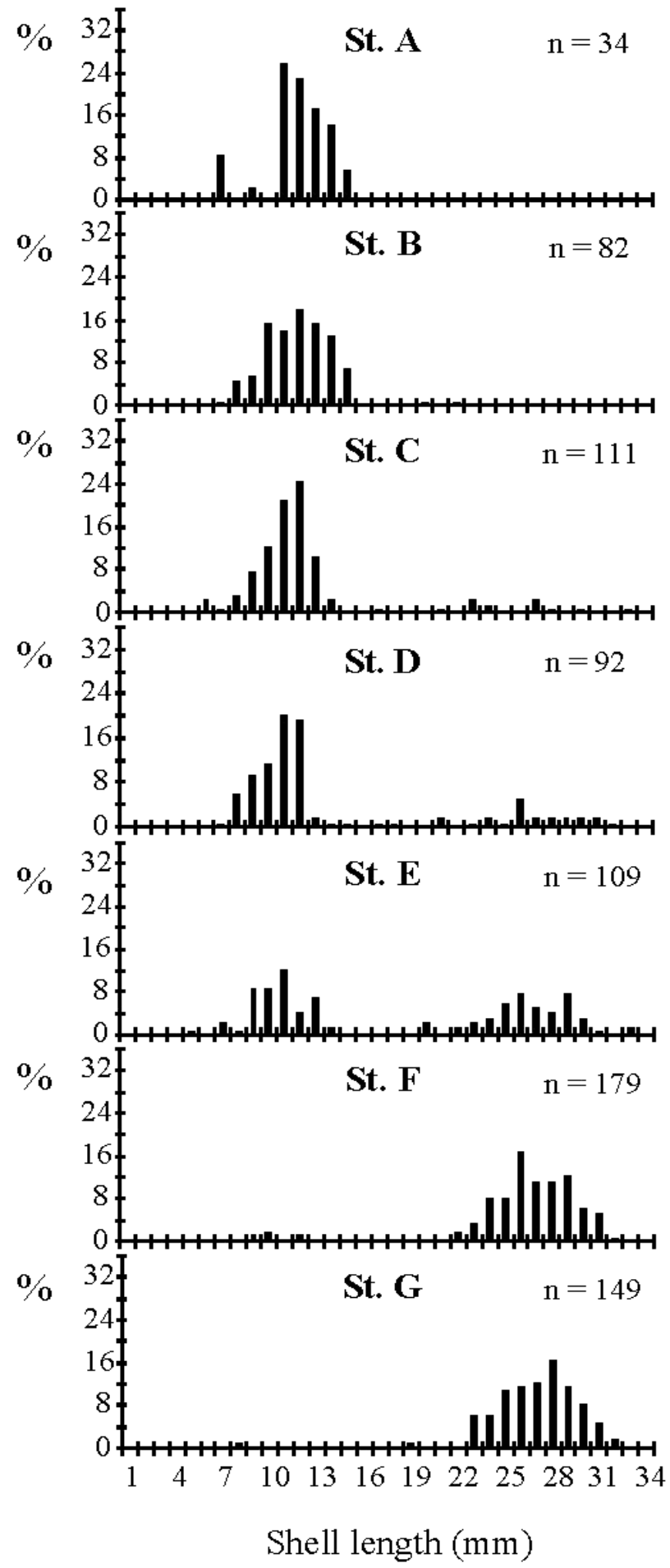

FIG. 4. - Juvenile (1994 cohort) distribution of Cerastoderma edule along the A-G transect in September 1994.

followed (an example from Stations 1 and 3 can be seen in Fig. 5). In spite of this, a general trend can be observed: growth of adults took place from April to August-September during both years studied. However, the 1994 cohort, which appeared at Sta- tion 1 in February (see recruitment section), was easy to distinguish from the older year classes and to monitor over time.

Juveniles inhabiting the area between Stations A and G grew mainly from August to the end of September 1994 and from May to September 1995 (Fig. 6A). Growth during winter was almost negligible. Juveniles established at Station 1 after winter grew mainly from May to September (Fig. 6B). There were significant differences between the monthly values of the mean shell length of juveniles inhabiting the area covered by Stations A-G and those inhabiting Station 1 from February to September 1995 (t-test; $\mathrm{p}<0.005$ ), but not in June (t-test; $\mathrm{p}=0.078$ ). The growth of the 1994 cohort was greater at Station 1 from February to May, but from July to September the highest growth took place at Stations A-G.

During the tagging-recapture experiment a total of 662 specimens were tagged and a total of 533 live individuals were recovered (Table 2). All the sizeincrement data pairs were used to estimate the von Bertalanffy growth function (VBGF). Additionally, 10 data pairs corresponding to the average growth of the newly settled 1994 cohort were included. The estimated parameter values of the growth function were: $\mathrm{L}_{\infty}=34.24 \mathrm{~mm}$ and $\mathrm{K}=0.754 \mathrm{y}^{-1}(\mathrm{~N}=543$, Residual Sum of Squares $=1001.646, r=0.968)$. Since the value obtained for $\mathrm{L}_{\infty}$ was below the maximum length observed on the Spiekeroog tidal flats, a second fit with $\mathrm{L}_{\infty}$ fixed at $40.0 \mathrm{~mm}$ was performed. It yielded $\mathrm{K}=0.404 \mathrm{y}^{-1}(\mathrm{~N}=543$, Residual Sum of Squares $=1090.429, r=0.966$ ), but the goodness of fit was very similar.

Residuals obtained after fitting a von Bertalanffy growth function to the initial and final lengths of the different experimental periods were compared using a one-way ANOVA. This test indicated a significant seasonal effect on growth rate $\left(\mathrm{F}_{11,521}=\right.$ 65.33, $\mathrm{p}<0.0001$, ANOVA test). The Tukey HSD test for unequal sample sizes (post-hoc comparisons) showed that there were no significant differences between the consecutive periods included from May to September ( $p>0.05$ ), but differences were found in comparing these with autumn and winter periods. Growth was higher from May to September 1994, when mean growth residuals showed positive values (with the exception of JulyAugust), whereas there was no growth from September to March 1995 (Fig. 7). The cessation of growth from July-August coincided with the formation of a growth ring at this time. 

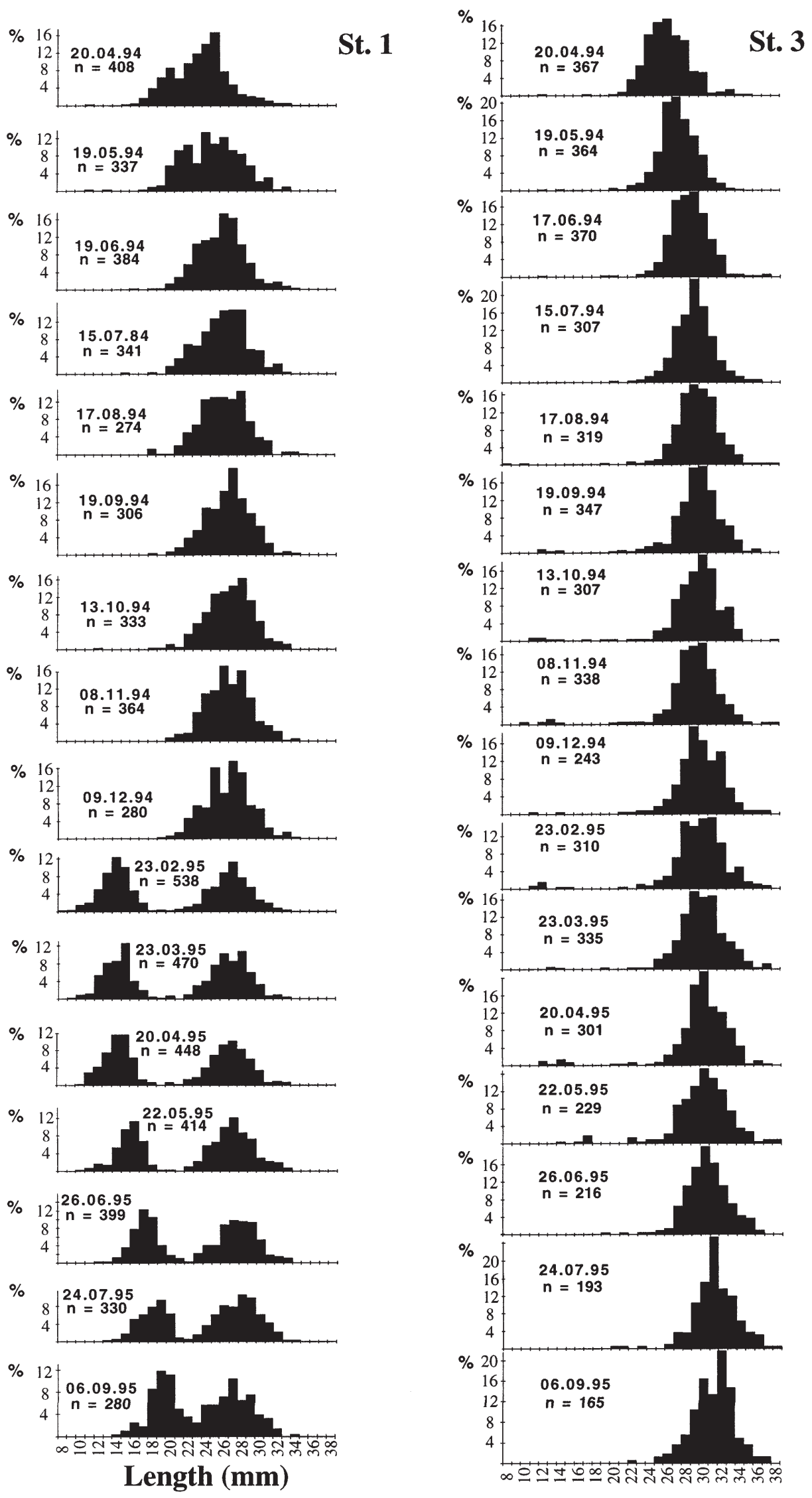

FIG. 5. - Length frequency distribution of Cerastoderma edule at Stations 1 and 3. 
A

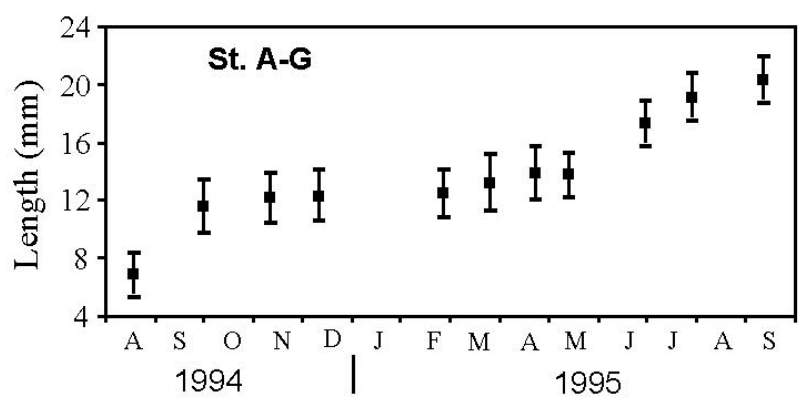

B

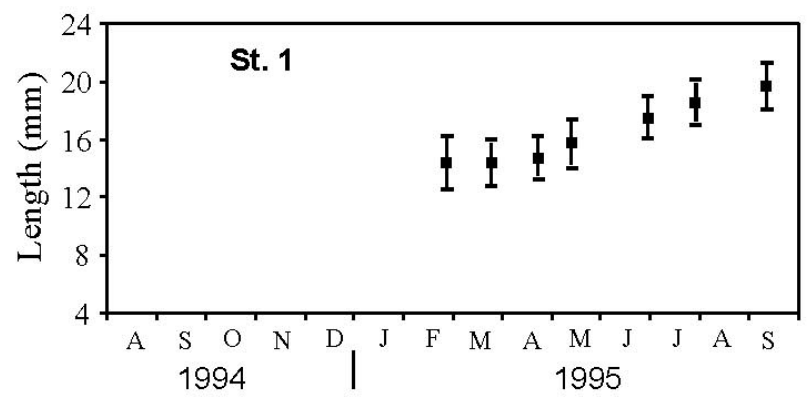

FIG. 6. - Mean length ( \pm S.D.) of the 1994 cohort. A: at Stations AG; B: at Station 1.

\section{Production}

Annual somatic production of $C$. edule was estimated to be 80.70, 50.87, 70.57 and $43.36 \mathrm{~g}$ AFDW ${ }^{*} \mathrm{~m}^{-2} \mathrm{y}^{-1}$ at Stations 1, 2, 3 and 4 respectively. These results were obtained by applying the values of the $\mathrm{K}$ parameter of the VBGF estimated in experimental cages at Station 4. Since submersion times varied along the tidal gradient, production figures at Stations 1,2 and 3 could be overestimates. In order to analyse the influence of the $\mathrm{K}$ parameter on the results, production was re-calculated with a linear relationship between submersion time and length assumed (Jensen, 1992b). The new results yielded values of 59.33, 38.16, 55.55 and $43.36 \mathrm{~g}_{\text {AFDW m }}^{-2} \mathrm{y}^{-1}$ at Stations 1, 2, 3 and 4 respectively (Table 3 ).

The distribution of annual somatic production (expressed as $\mathrm{g}$ AFDW $\mathrm{m}^{-2} \mathrm{y}^{-1}$ ) among the length

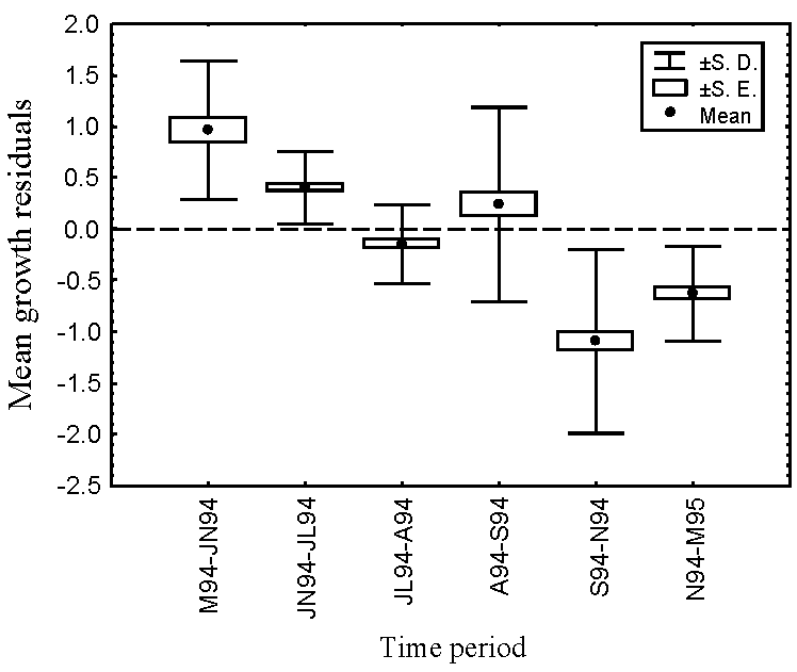

FIG. 7. - Mean growth residuals in consecutive periods of the tagging-recapture experiment.

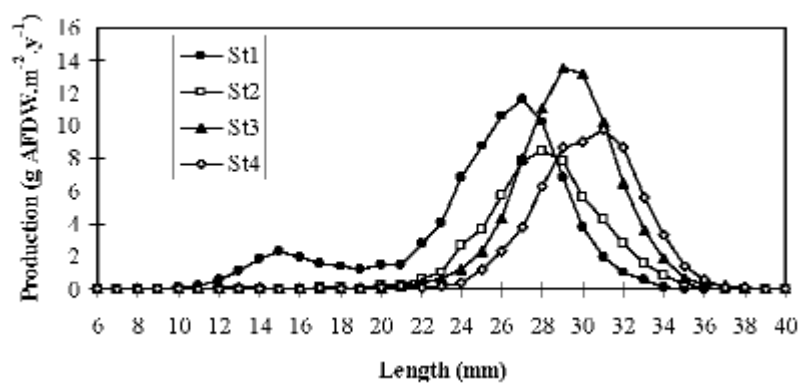

FIG. 8. - Distribution of annual production among the length classes of the Cerastoderma edule population at the different sampling stations.

classes is shown in Figure 8. Production increased with length until it reached its highest points at 27, 28, 29 and $31 \mathrm{~mm}$ shell length at Stations 1, 2, 3 and 4 respectively, decreasing thereafter. The contribution of the 1994 cohort was only seen at Station 1. This is consistent with the length frequency distribution of the population, which showed an increase in the modal values along the tidal gradient.

Mean annual biomass was highest at Station 3 (119.64 $\mathrm{g} \mathrm{AFDW} \mathrm{m}^{-2}$ ), whereas it was quite similar between the other stations $(90.15,82.32$ and 87.96 at Stations 1, 2 and 4 respectively). Annual somatic P/B ratio was highest at Station 1 (0.66) and showed similar values (0.46-0.49) at the other stations (Table 3).

TABLE 3. - Summary of Cerastoderma edule production

\begin{tabular}{lccrc}
\hline & Station 1 & Station 2 & Station 3 & Station 4 \\
\hline Annual somatic production (g AFDW m-2 $\mathrm{y}^{-1}$ ) & 59.33 & 38.16 & 55.55 & 43.36 \\
Mean annual biomass $\left(\mathrm{g} \mathrm{AFDW} \mathrm{m}{ }^{-2} \mathrm{y}^{-1}\right)$ & 90.15 & 82.32 & 119.64 & 87.96 \\
Annual P/B ratio $\left(\mathrm{n} \mathrm{m}^{-2}\right)$ & 0.66 & 0.46 & 0.46 & 0.49 \\
Mean abundance & 1181.6 & 727.5 & 942.6 & 615.5 \\
\hline
\end{tabular}


TABLE 4. - Instantaneous mortality rate $(\mathrm{Z})\left(\mathrm{y}^{-1}\right)$ of Cerastoderma edule estimated by simple linear regression at the time periods indicated.

\begin{tabular}{lccc}
\hline & $\begin{array}{c}\text { Apr. 1994- } \\
\text { Dec. 1994 }\end{array}$ & $\begin{array}{c}\text { Feb. 1995- } \\
\text { Sept. 1995 }\end{array}$ & $\begin{array}{c}\text { Apr. 1994- } \\
\text { Sept. 1995 }\end{array}$ \\
\hline Station A-G (juveniles) & & 0.36 & \\
Station 1 (juveniles) & & 1.07 & \\
Station 1 (adults) & 0.36 & 1.06 & 0.52 \\
Station 2 & 0.77 & 0.17 & 1.01 \\
Station 3 & 0.50 & 1.60 & 0.55 \\
Station 4 & 0.81 & 8.36 & 3.03 \\
& & & \\
\hline
\end{tabular}

\section{Mortality}

Adult population mortality rate $(\mathrm{Q})$ between May 1994 and September 1995 was 16.9, 56.4, 54.7 and 97.7\% at Stations 1, 2, 3 and 4 respectively. Mortality rate of the 1994 cohort at Station 1 from February 1995 to September 1995 was 49.8\%, which was higher than the values obtained for the juveniles at Stations A to $\mathrm{G}(\mathrm{Q}=38.5 \%)$ from September 1994 to September 1995.

Estimations of instantaneous mortality rate $(\mathrm{Z})$ by simple linear regression of the adult population from April 1994 to September 1995 yielded values of 0.52 year $^{-1}$ at Station 1, 1.01 year $^{-1}$ at Station 2, 0.55 year $^{-1}$ at Station 3 and 3.03 year $^{-1}$ at Station 4 (Table 4). Mortality increased in 1995 in such a way that $Z$ values between February and September 1995 at Stations 1, 3 and 4 were bigger than those between April and December 1994. This trend was not observed at Station 2. The instantaneous mortality rate from August 1994 to September 1995 for the 1994 cohort between Stations A to G yielded Z = $0.43 \mathrm{y}^{-1}$. Instantaneous mortality rate for the 1994 cohort inhabiting Station 1 from February 1995 to September 1995 yielded $1.07 \mathrm{y}^{-1}$.

\section{DISCUSSION}

\section{Recruitment}

In Neuharlingersieler Nacken, juveniles with shells longer than $3 \mathrm{~mm}$ (the 1994 cohort) inhabited only the area between the shoreline and the previously established population (Stations 1 to 4). This distribution pattern changed after winter, with the arrival of some juveniles at Station 1. Müller (1966) mentioned the presence of juveniles at all tidal levels in the same area in 1963, but reported no adults. The highest numbers of cockle recruits are usually found on the lower part of the intertidal flat (Kristensen, 1957; Reise, 1987). In the Skallingen peninsula (Danish Wadden Sea), settlement of cockle larvae took place in June-July in the entire area between the mean high and low water lines, but abundance increased with submersion time (Jensen, 1992b). This happened in 1982, following a severe winter when adult cockles were absent in the area. The period of initial settlement of larvae in Neuharlingersieler Nacken is not known and settlement could also have taken place on the entire tidal flat. The subsequent distribution pattern of the recruits observed in August may be due to events that happened after their settlement. Negative effects of adult cockles on their own recruitment due to juvenile ingestion by filtration (André and Rosenberg, 1991) or suffocation by bioturbation (De Montaudoin and Bachelet, 1996) have been given as reasons for differences in recruitment densities. Additionally, after initial spatfall, some species of molluscs may actively reenter the water column and undergo secondary dispersal as a result of drifting and floating. Baggerman (1953) mentioned that young cockle spat up to a size of nearly $2 \mathrm{~mm}$ are still transported by tidal currents. Armonies (1992) found cockles of 0.5 to $3.5 \mathrm{~mm}$ length drifting in tidal waters of the Wadden Sea. Other events like spat predation (Jensen and Jensen, 1985; Guillou and Tartu, 1994) and resuspension during sediment disturbance also affect the distribution pattern on the intertidal flat. The movement of juveniles observed in this study after winter, when they had a mean size $12 \mathrm{~mm}$ length, cannot be explained by drifting. Sörlin (1988) described the floating behaviour of Macoma balthica individuals from 4 to $14 \mathrm{~mm}$ long as a dispersal mechanism, but there are no data available for Cerastoderma edule. Since juveniles arrived at Station 1 after December in Neuharlingersieler Nacken, where the occurrence of storm surges that can destroy mussel beds in winter is common (Hertweck and Liebezeit, 1996), it seems probable that this movement was passive and caused by wave action and storms, which could have rolled small individuals to a lower level. In fact, passive displacement of cockles 2-3 $\mathrm{mm}$ long by rolling, caused by strong currents or wave action, have been mentioned by Jepsen (1965) and Meixner (1979). Kristensen (1957) suggested that, under strong wind conditions, even large cockles may be washed up and transported. 
TABLE 5. - Comparison of growth parameters estimated for Cerastoderma edule (asymptotic length $\mathrm{L}_{\infty}$; growth constant $\mathrm{K}$; age at which length is zero $t_{0}$ and growth index $\phi$ ).

\begin{tabular}{|c|c|c|c|c|c|}
\hline Area & $\mathrm{K}\left(\right.$ year $\left.^{-1}\right)$ & $\mathrm{L}_{\infty}(\mathrm{mm})$ & $\mathrm{t}_{0}$ & $\phi ’$ & Source \\
\hline Llanrhidian Sand (South Wales) & $\begin{array}{l}0.59 \\
0.62\end{array}$ & $\begin{array}{l}31.5 \\
31.5\end{array}$ & & $\begin{array}{l}2.77 \\
2.79\end{array}$ & Hancock (1965) \\
\hline Langerak, Aggersborg (Denmark) & $\begin{array}{l}0.248 \\
0.386\end{array}$ & $\begin{array}{c}54 \\
40.7\end{array}$ & $\begin{array}{c}-0.2 \\
-0.34\end{array}$ & $\begin{array}{l}2.86 \\
2.81\end{array}$ & Brock (1980) \\
\hline Rías Altas (North Spain) & 1.609 & 26.5 & 0.104 & 3.05 & Catoira et al. (1984) \\
\hline Ría de Arosa (North Spain) & 0.951 & 41.226 & 0.083 & 3.21 & Pérez and Roman (1984) \\
\hline Ría de Arosa & $\begin{array}{l}0.023 \\
0.022\end{array}$ & $\begin{array}{c}31.4 \\
25.90\end{array}$ & $\begin{array}{l}283.51 \\
291.34\end{array}$ & $\begin{array}{l}1.36 \\
1.17\end{array}$ & García et al. (1987) \\
\hline Algeciras Bay (South Spain) & 0.18 & 36 & -0.05 & 2.37 & Guevara and Niell (1989) \\
\hline Mundaca estuary (North Spain) & 0.026 & 28.27 & 8.998 & 1.32 & Iglesias and Navarro (1990) \\
\hline German Wadden Sea & 0.404 & 40 & & 2.81 & (this study) \\
\hline
\end{tabular}

\section{Growth}

The growing season of juveniles and adults took place from April to August-September, coinciding with the phytoplankton cycle in the area. The highest values of chlorophyll- $a$ occurred in spring and summer, as in other Wadden Sea areas (e.g. Cadée and Hegeman, 1979). Similar seasonality in growth has been found in the Danish (Jensen, 1992b) and German (Dörjes, 1992) Wadden Sea, and in the French Atlantic coast (Guillou and Tartu, 1994; Sauriau and Kang, 2000).

The von Bertalanffy growth function showed a good fit to the size increment data pairs. There are several estimations of the growth parameters for $C$. edule in the literature (Table 5). The $\mathrm{K}$ values obtained for the cockle populations inhabiting Neuharlingersiel are intermediate compared with other values reported, although growth intensity is best compared using $\phi$ '. Growth index estimated here are very similar to the ones reported in South Wales and Denmark. Values for north Spain are very variable.

Other studies on $C$. edule growth have provided data on length-at-age. The 0-group cohort achieved a mean size of $7.4,13.4$ and $14.5 \mathrm{~mm}$ in the first winter (1987) at Jade Bucht (German Wadden Sea), Groningen and Balgzand (Dutch Wadden Sea) respectively (Ducrotoy et al., 1991). In the present study, the 1994 cohort had a mean size of $12.3 \mathrm{~mm}$ in December, which is similar to their size in the Western Wadden Sea where, in addition, recruit densities were comparable. The high density of recruits at Jade Bucht (2975 ind $\cdot \mathrm{m}^{-2}$ ) could explain these dif- ferences in growth rates. Our results coincide with those obtained in a neighbouring area (Dörjes, 1992) and show a higher growth than those reported in the Danish Wadden Sea (Jensen, 1992b, 1993) and Wales (Jones, 1979), but are lower than those reported in British waters (Boyden, 1972).

The presence of a ring on the edge of most shells of the adults collected in mid- August 1994, which was not observed in samples collected in mid-July, showed that they were produced between the two periods. This has to be interpreted as a sign of some event of growth cessation, which coincides with the tagging-recapture experiment results. These showed that there was a reduction in growth from July to August (Fig. 7). The summer ring formation could be linked to high temperatures and/or spawning events. In fact, the highest water temperatures were recorded in July and August (Fig. 2). Spawning events may also be responsible for ring formation as cockle spawning takes place in summer (Dörjes, 1992; Guillou et al., 1992). In any case, independently of the cause of ring formation, the counting of growth rings to determine age can lead to an underestimation of growth if each ring, as usually occurs, is considered to correspond to one year.

Differences in mean shell length of the 1994 cohort between Stations A to G and Station 1 cannot be totally explained by differences in submersion time: from February to May growth was highest at Station 1 and from July to September it was highest at Stations A to G. Thus, other factors have to be considered: intraspecific competition between the adults and the recruits at Station 1 could have affected the growth of recruits. As Jensen (1993) argued, 
growth in cockles increases with the duration of tidal submersion, but a density-dependent mechanism is the most likely process causing growth differences. Comparison of mean densities of recruit and adult cockle groups at Station 1 in these two periods gives no evidence of a density-dependent mechanism, since the values of the proportion adults/recruits varied between 1.1 and 1.6 from February to May and between 1.2 and 1.6 from July to September. Therefore, the possible explanation could be related to the amount and quality of the phytoplankton available as food. The annual cycle of the phytoplankton in Norderney, East Frisian Islands (Germany), reveals a pattern where the Phaeocystis globosa bloom either follows, or intersects with, the diatom bloom (Rahmel et al., 1995). The solitary cells of Phaeocystis provide suitable food for Macoma balthica, but the colony form has no value as a food resource (Kamermans, 1994). Mytilus edulis bigger than $3 \mathrm{~cm}$ are able to filter $P$. globosa colonies, while young mussels $(<3 \mathrm{~cm})$ reduce their clearance rates (Petri et al., 1999). The nutritional value of Phaeocystis for Cerastoderma edule remains unclear.

\section{Production}

Although the production for Stations 1, 2 and 3 differed, depending on the values of the K-parameter of the VBGF used for calculation, the results gave similar relative values and their interpretation is similar. The highest production took place at Station 1 , but the mean biomass was not the highest because the size (and weight) of the individuals was smaller there. However, at Station 3, where the specimens were bigger, the mean biomass was the highest. Dörjes et al., (1986) mentioned production values of 20-40 g AFDW. $\mathrm{m}^{-2}$, with maxima exceeding $100 \mathrm{~g}$ AFDW $\cdot \mathrm{m}^{-2}$, in Nordeney (East Frisian Islands, Germany). In the Danish Wadden Sea Jensen (1993) estimated values ranging from 7.6 to $101.6 \mathrm{~g}$ AFDW $\cdot \mathrm{m}^{-2}$ depending on the year. Sauriau and Kang (2000) estimated a total annual production of $32.5 \mathrm{~g}$ AFDW. $\mathrm{m}^{-2}$ in the Marennes-Oléron Bay (French Atlantic coast), with a higher contribution corresponding to the 0 -group and 1-yr-old cockles. The main contribution to production in the cockle population in Neuharlingersieler Nacken is based on 2- to 3-year old cockles, with lengths of 26 to 31 $\mathrm{mm}$. P/B ratios obtained (ranging from 0.46 to 0.66 ) are comparable with the ones obtained by Jensen (1992a) at Skallingen (Danish Wadden Sea).

\section{Mortality}

In the population studied it does not seem appropriate to use the mortality estimation methods based on age composition, due to the assumptions that these methods require (Ricker, 1975). Specifically, the mortality rate $\mathrm{Z}$ of the different cohorts and the inter-annual recruitment must be constant (steadystate population). The cockle population in Neuharlingersieler Nacken did not have constant recruitment during the period studied and cohorts could not be identified clearly from the length frequency distributions. However, Z seems to be constant between cohorts because the length frequency distributions did not show gaps, and shape changes between months were mainly due to growth. For these reasons, it was decided to estimate $\mathrm{Z}$ by simple linear regression between the logarithm of the variation in the whole population (mixing cohorts) throughout the studied period.

Estimations of instantaneous mortality rate (Z) for the Cerastoderma edule adult population in Neuharlingersieler ranged from 0.52 to $3.03 \mathrm{y}^{-1}$ during the whole study period. These values are similar to those previously reported by Beukema (1982b) for the tidal flat areas of the Dutch Wadden Sea (ranged from 0.29 to $3.22 \mathrm{y}^{-1}$ ). The winter of 199495 did not produce the heavy mortalities observed in other studies (Beukema 1979; Ducrotoy et al., 1991; Dörjes, 1992), but major losses occurred in the following winter (Dittmann, 1999).

The highest mortality was found at Station 4, where only 29 ind $\cdot \mathrm{m}^{-2}$ remained at the end of the study (September 1995). Several factors could be responsible for the decline in cockles: predation, increased drag by epibionts, parasitism and mussel biodeposition. Small cockles (spat and one-year-old) have many predators (crabs, fishes) on tidal flats (Jensen and Jensen, 1985; van der Veer et al. 1998). Cockles from 1 to $3 \mathrm{~cm}$ in shell length are an important prey for oystercatchers (Haematopus ostralegus), but cockles bigger than $3 \mathrm{~cm}$ have no predators (Reise, 1985). The proportion of cockles bigger than $30 \mathrm{~mm}$ in length at Station 4 was $75 \%$ in March 1995, so predation cannot explain the high mortality observed later. The increased risk of dislodgement caused by drag by epibionts described in other molluscs (Ansell et al., 1988), which could explain the losses of individuals, should be expected to occur mainly during the stormy winter season. Instead of this, the high mortality observed at this station occurred mainly between March and May 1995. The 
abundant presence of Mytilus edulis spat attached to live and dead adult cockle shells at Station 4 and the later development of these clumps into real mussel beds, which produce large amounts of faeces and pseudofaeces, could have had consequences on the macrofauna, as Kröncke (1996) demonstrated in a nearby area. Hertweck and Liebezeit (1996) commented that between 1991 and 1993 the accumulation of biodepositional fine-grained material in a mussel bed in Neuharlingersieler Nacken began in June 1992, ten months after colonisation by mussels; and a mud layer of $2 \mathrm{~cm}$ thickness under the live mussels was clearly recognisable in December 1992. For this region, Flemming and Delafontaine (1994) reported one of the highest biodeposition rates of Mytilus edulis. After summer 1994, an increase in the mud content at Station 4 was observed, which was quantified from March to September 1995 (Table 1). Then, the high mortality at this station was probably due to suffocation by excessive sedimentation and/or low oxygen levels as a result of decomposition of pseudofaeces in biodeposited muds. Although the negative effect of mussels attachment on mortality of adult cockles could not be proved by Ramón (1996) during six-month in situ caging experiments, Meixner (1979) reported that cockle populations living underneath mussel beds in the German Wadden Sea were destroyed within 4 years of the establishment of new beds. It thus seems that the influence of mussel beds on adult cockle populations can be detected in timeperiods of over half a year.

In conclusion, the population of Cerastoderma edule established at Neuharlingersieler Nackel was affected by different factors related to the tidal level of the inhabited area. Displacement of young cockles from the upper to lower levels of the intertidal and heavy mortality of adults at their lower limit of occurrence affected their dynamics. Following the model of Ducrotoy et al., (1991), which describes the different phases of Cerastoderma edule population fluctuations, the population studied here was in an advanced upholding phase, characterised by the presence of several age-classes and higher densities of older ones. Any instability (mortality of older animals or poor recruitment) will accelerate the step to the decline phase.

\section{ACKNOWLEDGEMENTS}

I am grateful to M.T. Delafontaine and I. Kröncke for their support during this research and to the Senckenberg and Alfred-Wegener Institutes for providing laboratory facilities. This work was supported by the Spanish Ministry of Education and Science (Grant PF93 37284469), by the Federal Environmental Agency, the Environmental Research Plan of the Ministry of the Environment, Nature Conservation and Nuclear Safety of Germany (Grant 03F0112A), and by the State of Niedersachsen. This is Publ. No. 321 of the project Ecosystem Research Wadden Sea.

\section{REFERENCES}

André, C. and R. Rosenberg. - 1991. Adult-larval interactions in the suspension-feeding bivalves Cerastoderma edule and Mya arenaria. Mar. Ecol. Progr. Ser., 71: 227-234.

Ansell, A., D.L. Robb and H.T. Powell. - 1988. Algal-induced dislodgement as a cause of bivalve mortality on some Scottish beaches. J. Mar. Biol. Assoc. U.K., 68: 219-233.

Armonies, W. - 1992. Migratory rhythms of drifting juvenile mollusc in tidal waters of the Wadden Sea. Mar. Ecol. Prog. Ser. 83: $197-206$

Baggerman, B. - 1953. Spatfall and transport of Cardium edule L. Arch. Néerl. Zool., 10: 315-342.

Bertalanffy, von L. - 1938. A quantitative theory of organic growth: Inquiries on growth laws. II. Hum. Biol., 10(2): 181-213.

Beukema, L.J. - 1979. Biomass and species richness of the macrobenthic animals living on a tidal flat area in the Dutch Wadden Sea, effects of a severe winter. Neth. J. Sea Res., 13(2): 203-223.

Beukema, L.J. - 1982a. Annual variation in reproductive success and biomass of the major macrozoobenthic species living in a tidal flat area of the Wadden Sea. Neth. J. Sea Res., 16: 37-45.

Beukema, L.J. - 1982b. Calcimass and carbonate production by mollusc on the tidal flats in the Dutch Wadden Sea: II the edible cockle, Cerastoderma edule. Neth. J. Sea Res., 15(3/4): 391-405

Beukema, L.J. - 1992. Long-term and recent changes in the benthic macrofauna living on tidal flats in the western part of the Wadden Sea. Neth. Inst. Sea Res. Publ. Ser. No. 20, 135-141.

Bhattacharya, C.G. - 1967. A simple method of resolution of a distribution into Gaussian components. Biometrics, 23: 115-135.

Bouma, H., J.M.C. Duiker, P.P. de Vries, P.M.J. Herman and W.J. Wolff. - 2001. Spatial pattern of early recruitment of Macoma balthica (L.) and Cerastoderma edule (L.) in relation to sediment dynamics on a highly dynamic intertidal sandflat. J. Sea Res. 45(2): 79-93.

Boyden, C.R. - 1972. Aerial respiration of the cockle Cerastoderma edule in relation to temperature. Comp. Biochem. Physio. 43: 697-712.

Brock, V. - 1980. Evidence for niche differences in sympatric populations of Cerastoderma edule and C. lamarcki. Mar. Ecol. Progr. Ser., 2: 75-80.

Cadée, G.C. and J. Hegeman. - 1979. Phytoplankton primary production, chlorophyll and composition in an inlet of the western Wadden Sea area (Marsdiep). Neth. J. Sea Res., 13(2), 224-241.

Catoria, J.L., D. Martinez and A. De Coo. - 1984. Contribución al estudio del crecimiento del berberecho (Cerastoderma edule L.) en las Rías Altas gallegas. Actas do IV Simposio Ibérico de Estudos do Benthos Marinho, Vol. II: 295-306.

Crisp, D.J. - 1984. Energy flow measurements. In: N.A. Holme and A.D. McIntyre (eds.), Methods for the study of marine benthos, pp. 284-372. Blackwell, London.

De Montaudouin, X. - 1996. Factors involved in growth plasticity of cockles Cerastoderma edule L., identified by field survey and transplant experiments. J. Sea Res., 36(3/4): 251-265.

De Montaudouin, X. and G. Bachelet. - 1996. Experimental evidence of complex interactions between biotic and abiotic factors in the dynamics of an intertidal population of the bivalve Cerastoderma edule. Oceanologica Acta, 19(3-4): 449-463. 
Dittmann, S. - 1999. The Wadden Sea ecosystem. Stability properties and mechanisms. Springer, Berlin, Heidelberg, New York, $307 \mathrm{pp}$.

Dörjes, J., H. Michaelis and B. Rhode. - 1986. Long-term studies of macrozoobenthos in intertidal and shallow subtidal habitats near the island of Norderney (East Frisian coast, Germany). Hydrobiologia, 142: 217-232.

Dörjes, J. - 1992. Zur Populationsdynamik von Cerastoderma edule (L.) nach dem Eiswinter 1978/79 am Beispiel zweier Stationen der Jadewatten (Nordsee) in der Zeit von 1979-1988. Senckenbergiana marit. 22(1/2): 21-28.

Ducrotoy, J.P. and M. Desprez. - 1986. Evolution spatio-temporelle de populations estuariennes de bivalves, liée à des perturbations naturelles ou artificielles. Haliotis, 15: 283-289.

Ducrotoy, J.P., H. Rybarczyk, J. Souprayen, G. Bachelet, J.J. Beukema, M. Desprez, J. Dörjes, K. Essink, J. Guillou, H. Michaelis, B. Sylvand, J.G. Wilson, B. Elkaïm and F. Ibanez. - 1991. A comparison of the population dynamics of the cockle (Cerastoderma edule, L.) in North-Western Europe. In: M. Elliot and J.P. Ducrotoy (eds.), Estuaries and Coast: Spatial and Temporal Intercomparisons, pp. 173-183. Olsen and Olsen.

Flemming, B.W. and M.T. Delafontaine. - 1994. Biodeposition in a juvenile mussel bed of the east Frisian Wadden Sea (Southern North Sea). Neth. J. Aquat. Ecol., 38: 289-297.

Flemming, B.W. and N. Nyandwi. - 1994. Land reclamation as a cause of fine-grained sediment depletion in backbarrier tidal flats (southern North Sea). In: K. Essink and V.N. de Jonge (eds.), Particles in estuaries and coastal waters, Proc. ECSA23 Symp., Haren (The Netherland), 1993. Neth. J. Aquat. Ecol., 28: 299-307.

Forschungsstelle Küste. - 1995. Überwachungs der niedersächsischen küstengewässer. I. Routine untersuchungen 1994. Dienstber. Forschungsstelle Küste 26/1995, Norderney, 97 pp.

Forschungsstelle Küste. - 1996. Überwachungs der niedersächsischen küstengewässer. I. Routine untersuchungen 1995. Dienstber. Forschungsstelle Küste 11/1996, Norderney, 77 pp.

García, A., J. Otero, A. De Coo, M.C. López, M.J. Carballal and J. Otero Gonzalez - 1987. Contribución al estudio del berberecho (Cerastoderma edule L.) en la Ría de Arosa. Cuad. Marisq., 11: 333-352.

Guevara, J.M. and F.X. Niell. - 1989. Growth rates in a continuously immersed population of Cerastoderma edule L. In: J. Ros (ed.), Topics in marine biology. Proceedings of the $22^{\text {nd }}$ European Marine Biology Symposium, pp. 483-489. Sci. Mar. 53:2-3.

Guillou J. and C. Tartu. - 1994. Post-larval and juvenile mortality in a population of the edible cockle Cerastoderma edule (L.) from Northern Brittany. Neth. J. Sea Res., 33(1): 103-111.

Guillou J., G. Bachelet and M. Glémarec. -1992. Influence des fluctuations de température sur la reproduction et le recrutement de la coque Cerastoderma edule (L.). Ann. Inst. océanogr. Paris, 68: 65-74.

Hancock, D.A, - 1965. Graphical estimation of growth parameters. J. du Cons. 29: 340-351.

Hertweck, G. and G. Liebezeit. - 1996. Biogenic and geochemical properties of intertidal biosedimentary deposits related to Mytilus beds. P.S.Z.N.I. Mar. Ecol. 17(1-3): 131-144.

Iglesias, J.I.P. and E. Navarro. - 1990. Shell growth of the cockle Cerastoderma edule in the Mundaca estuary (North Spain). $J$. Moll. Stud. 56: 229-238.

Jensen, K.T. - 1992a. Macrozoobenthos on an intertidal mudflat in the Danish Wadden Sea: comparisons of surveys made in the 1930s, 1940s and 1980s. Helgol. Meeres., 46: 363-376.

Jensen, K.T. - 1992b. Dynamics and growth of the cockle, Cerastoderma edule, on an intertidal mud-flat in the Danish Wadden Sea: effects of submersion time and density. Neth. J. Sea Res., 28(4): 335-345

Jensen, K.T. - 1993. Density-dependent growth in cockles (Cerastoderma edule), evidence from interannual comparisons. $J$. mar. biol. Ass. U. K., 73, 333-342.

Jensen, K.T. and J.N. Jensen, - 1985. The importance of some epibenthic predators on the density of juvenile benthic macrofauna in the Danish Wadden Sea. J. Exp. Mar. Biol. Ecol. 89: $157-174$

Jepsen, U. - 1965. Die Struktur der Wattenbiozönosen im Vormündungsgebiet der Elbe. Arch. Hydrobiol. Suppl., 29: 252-370.

Jones, A.M. - 1979. Structure and growth of a high-level population of Cerastoderma edule (Lamellibranchiata). J. Mar. Biol. Assoc., 59(2), 277-287.
Kamermans, P. - 1993. Food limitation in cockles (Cerastoderma edule L.): influences of location on tidal flat and of nearby presence of mussel beds. Neth. J. Sea Res., 31: 71-81.

Kamermans, P. - 1994. Nutritional value of solitary cells and colonies of Phaeocystis sp. for the bivalve Macoma balthica. Ophelia, 39(1): 35-44.

Kristensen, I. - 1957. Differences in density and growth in a cockle population in the Dutch Wadden Sea. Archs. Neèrl. Zool., 12: 351-453.

Kröncke, I. - 1996. Impact of biodeposition on macrofaunal communities in intertidal sandflats. P.S.Z.N.I. Mar. Ecol., 17(1-3): 159-174.

Meixner, R. - 1979. Die Fischerei auf Herzmuscheln (Cardium edule) im niedersächsischen Wattenmeer. Arch. Fish.Wiss., 29(3): 141-153

Müller, C.D. - 1966. Das Ostfriesische Watt von Neuharlingersieler Nacken bis Harlesiel. Biologisch-sedimentologische untersuchung mit Folgerungen für den Küstenschutz. Forschungsstelle Nordeney Jahresbericht: 139-154.

Nehls, G. and M. Thiel. - 1993. Large-scale distribution patterns of the mussel Mytilus edulis in the Wadden Sea of Schleswig-Holstein, do storms structure the ecosystem? Neth. J. Sea Res., 31(2): 181-187.

Pauly, D. and J.L. Munro. - 1984. Once more on the comparison of growth in fish and invertebrates. Fishbyte 2:21.

Pérez Camacho, A. and G. Román. - 1984. Crecimiento, reproducción, mortalidad y producción del berberecho Cerastoderma edule (L.), en la Ría de Arousa. Cuad. Area Cienc. Mariñ. Sem. Est. Gal.,: 499-507.

Petri, G.F., H. Donar and E. Vareschi. - 1999. Investigations on uptake and utilization of Phaeocystis globosa colonies by the blue mussel Mytilus edulis. Senckenbergiana marit., 29(Suppl.): 117-118.

Press, W. H., B. P. Flanner, S. A. Teukolsky and W. T. Vetterling. - 1986. Numerical recipes. The art of scientific computing. Cambridge University Press, Cambridge, $818 \mathrm{pp}$.

Rahmel J., M. Bätje, H. Michaelis and U. Noack. - 1995. Phaeocystis globosa and the phytoplankton succession in the East Frisian coastal waters. Helgoländ. Meeres. 49: 399-408.

Ramón. M. - 1996. Relationships between the bivalves Mytilus edulis L. and Cerastoderma edule (L) in a soft bottom environment, an example of interaction at small spatial scale. J. Exp. Mar. Biol. Ecol., 204(1-2): 179-194.

Reise, K. - 1985. Tidal flat ecology. An experimental approach to species interaction. Ecological studies, V. 54, W.D. Billings, F. Golley, O.L. Lange, J.S. Olson and H. Remmert (eds.), Springer-Verlag, Berlin Heidelberg.

Reise, K. - 1987. Distribution and abundance of small and juvenile macrofauna on the tidal flats in the North Frisian Wadden Sea. Biologiske Meddr. 31: 7-25.

Reise, K., E. Herre and M. Sturm. - 1994. Biomass and abundance of macrofauna in intertidal sediments of Königshafen in the northern Wadden Sea. Helgoländ. Meeres. 48: 201-215.

Ricker, W.E. - 1975. Computation and interpretation of biological statistics of fish populations. Bull. Fish. Res. Board. Can. 191: 382 p.

Sauriau, P.-G. and C.-K. Kang. - 2000. Stable isotope evidence of benthic microalgae-based growth and secondary production in the suspension feeder Cerastoderma edule (Mollusca, Bivalvia) in the Marennes-Oléron Bay. Hydrobiologia, 440: 317-329.

Sörlin, T. - 1988. Floating behaviour in the tellinid bivalve Macoma balthica (L.) Oecologia, 77: 273-277.

Strasser, M. - 2000. Recruitment patterns of selected Wadden Sea fauna after winters of differing severity. Ber. Polarforsch., 377: $127 \mathrm{pp}$.

Strasser, M. and C.P. Günter. - 2001. Larval supply of predator and prey: temporal mismatch between crabs and bivalves after a severe winter in the Wadden Sea. J. Sea Res., 46: 57-67.

van der Veer, H.W., R.J. Feller, A. Weber and J.I. Witte. - 1998 Importance of predation by crustaceans upon bivalve spat in the intertidal zone of the Dutch Wadden Sea as revealed by immunological assays of gut contents. J. Exper. Mar. Biol. Ecol., 231 (1): 139-157.

Zwarts, L. - 1991. Seasonal variation in body weight of the bivalves Macoma balthica, Scrobicularia plana, Mya arenaria and Cerastoderma edule in the Dutch Wadden Sea. Neth. J. Sea Res. 28(3): 231-245.

Scient. ed.: P. Abelló 
